\title{
INNOVATIVE ASPECTS OF IMPROVING THE EDUCATIONAL PROCESS IN HIGHER EDUCATION
}

\author{
Shukhrat Boymuradov \\ Umida Hodjaeva \\ Tashkent Medical Academy, Uzbekistan
}

\begin{abstract}
In modern conditions, the wide introduction of information and communication technologies (ICT) into the social sphere is of great importance, therefore the development of science is impossible without the use of new educational technologies.

The purpose of the research is to develop scientific and methodological provisions for the use of info communication technologies and internationalize professional training of medical students.
\end{abstract}

The object of the research is the process of improving the professional training of students in medical universities.

The subject of the research is the pedagogical and organizational-content conditions for improving the information training of students of medical schools on the basis of the use of ICT in teaching.

The hypothesis of the research is that increasing the information training of students of medical schools in professional activities based on the use of ICT will be effective if:

- the scientifically grounded way of preparation of students for professional activity with use of ICT within the framework of existing State educational standards of the higher vocational training is offered;

- a model for the formation of cognitive activity of students of medical schools based on the use of ICT is developed.

The methodological basis of the research are the ideas of the theory of a intergral educational process, the concept of personal developmental learning, the concept of education using computer technology, the concept of the formation of the information culture of the individual in general and the teacher, in particular [2,4,5,7,8].

Conclusions: The analysis of the state of the development of information technologies in education, the disclosure of the specifics of the use of ICT allow to develop organizational and semantic conditions for the formation of elements of the methodical system of using modern information technologies in vocational training of medical students.

Keywords: Higher education, information and communication technologies, innovation, improvement of educational process.

\section{Introduction}

The Tashkent Medical Academy (TMA) pays much attention to the improvement of the educational and methodical process, the development of 
innovative didactic systems. At the same time, medical pedagogical science is based on a common platform for the methodology of the higher school educational process, which is built on a number of didactic principles, including accessibility, scientific, systematic, visual approach.

The educational process in TMA is constantly being improved due to new information technologies that allow searching new information resources. And at the same time the most important form of education in our medical college is a lecture. Its significance lies in the fact that it is not possible to replace the live communication of the lecturer with students even with the Internet that has become so popular among young people. Teaching staff (TS) of TMA uses modern lecture forms in the framework of innovative teaching: an integral lecture; problem lecture; lecture-visualization; lecture mobilizing motivational, gnostic and controlling functions in teaching.

The main component of the teaching activity of the teaching staff has always been the desire not only to master innovative educational technologies, but also the most active participation in the development of new didactic systems from the perspective of evidence-based medicine.

The undoubted achievement of recent years was strengthening of the methodology of visualization of teaching. Modern educational systems are designed to help to solve the problems facing the higher medical school: to train highly qualified specialists in various fields of knowledge, ready for responsible and effective activity in their specialty at the level of world standards.

All world experience shows that now in the global economy the information and communication technologies sector, including the production of computer and telecommunication technologies, software development and the provision of a wide range of interactive services, is becoming increasingly important. It should not be forgotten that the development of ICT directly affects the level of the country's competitiveness, allows the collection and aggregation of huge amounts of information, opens wide opportunities for governance at the strategic level.

Many aspects of innovative educational technologies, the results of scientific research and the development and implementation of authors' techniques related to lecture work, the organization of independent work of students, interdisciplinary integration, etc. are used in the activity of the TS of TMA.

At present, the trend towards the formation of a common information space has become evident, both within the framework of individual educational institutions, and in the perspective for the entire educational system. In addition to the organizational structure of this space and actively developing nowadays specialized software on the basis of which its functioning is realized, paper information carriers - methodical and educational literature, periodicals for medical educational institutions - can be considered an integral part of common 
information space. In this connection, in particular, there arises the task of efficient integration of computer and traditional information support tools.

The main drawback of existing information resources used in medical universities is their practical isolation from the content and methods of teaching specific disciplines. It can be noted that the means of informatization used in higher educational institutions discord methodical training systems, which are understood as a set of goals, content, methods, forms and means of teaching. The development and application of the information environment of the university can become a real ground for solving this problem. Consideration of all components and environment resources, the features of components of the methodical system will maximize the resources of the environment to the established practice of training, make the informatization process as effective as possible and will serve as another factor that facilitates the integration and unification of information resources and technologies.

Many authors note the high efficiency and broad pedagogical possibilities of using modern multimedia computers in the learning process, but on the condition that the didactic and psychological principles of interaction of the computer with students, developed by modern pedagogical science, are taken into account in the process of creating a pedagogical software.

In the works of several authors, the following drawbacks of modern teaching systems are noted: the teaching action does not take into account the individual characteristics of the trainee to the full; most systems can not identify those gaps in mental activity that have caused difficulties in students (Боймурадов, 2016; Боймурадов, 2014; Бахарева, 2000; Васильков, 2004; Долинер, 2003; Мирзоева, 2004; Computers and Medical..., 1998).

The purpose of the research is to develop scientific and methodological provisions for the use of info communication technologies and internationalize professional training of medical students.

The object of research is the process of improving the professional training of students in medical universities.

The subject of the research is the pedagogical and organizational-content conditions for improving the information training of students of medical schools on the basis of the use of ICT in teaching.

The hypothesis of the research is that increasing the information training of students of medical schools in professional activities based on the use of ICT will be effective if:

- the scientifically grounded way of preparation of students for professional activity with use of ICT within the framework of existing State educational standards of the higher vocational training is offered;

- a model for the formation of cognitive activity of students of medical schools based on the use of ICT is developed. 
The methodological basis of the research are the ideas of the theory of a intergral educational process, the concept of personal developmental learning, the concept of education using computer technology, the concept of the formation of the information culture of the individual in general and the teacher, in particular $[2,4,5,7,8]$.

The theoretical basis of the study is the pedagogical basis for the use of ICT, which is reflected in the work of some authors (Васильков, 2004; Гулякин, 2004; Мирзоева, 2004; Романов, 2002). The content of the term „personal information culture", inextricably linked with the social nature of a person, is disclosed in several publications (Боймурадов, 2016; Боймурадов, 2014; Гулякин, 2004; Кочетков, 2002; Романов, 2002), the problems of higher education informatization are reflected in the works of authors (Бахарева, 2000; Васильков, 2000; Гулякин, 2004; Долинер, 2003; Кочетков, 2002). The use of telecommunication technologies in the teaching and management of the educational process is reflected in the works of authors (Lyon, 2001; Kridl et al, 2001; Гулякин, 2004; Долинер, 2003; Кочетков, 2002; Мирзоева, 2004). The work of a number of authors is devoted to the use of new ICT in medicine (Lyon, 2001; Kridl et al, 2001; Васильков, 2000; Долинер, 2003; Кочетков, 2002; Романов, 2002). Information culture as knowledge about the structure, functioning of the information environment as well as skills necessary for interaction with it both by traditional means and by means of information technologies, is considered in the following works (Lyon, 2001; Kridl et al, 2001; Шапошникова, 2000). Inclusion in the content of the information culture of the axiological, ideological and other components reflecting the motivational and semantic sphere of the individual is revealed in studies (Kridl et al, 2001; Романов, 2002; Шапошникова, 2000). The social aspect of an individual's information culture is defined as the degree of mastering social information, as a set of principles and real mechanisms that ensure positive interaction in the information process, both as an individual and humanity as a whole. The formation of the information culture of the teacher, his preparation for the application of information technology in professional and pedagogical activity; definition of goals, content, methodology and methods of teaching informatics for future teachers are investigated in the following works (Lyon, 2001; Kridl et al, 2001; Мирзоева, 2004; Романов, 2002).

The problem of internationalization of higher education is linked with the need for training of highly qualified competitive specialists of international level, able to operate in global labor market requirements.

On the other hand, currently, there is a pressing need of active change of higher education, in particular, closer cooperation in the field of mutual exchange of experience between the higher educational institutions of the leading European countries who are recognized leaders in the field of education. The modern system 
of higher medical education is designed to improve the training of multiple personality, capable of active social adaptation in society. Today, the internationalization of higher education is a necessary condition for successful development of the university. When there is deep integration of education between foreign universities there develop the processes of implementing priority development programs of staff training.

Internationalization processes include the integration of higher education in the international educational community through the implementation of exchange programs between the actors of the global educational space: students, faculty, research staff (in the form of training, workshops, seminars, master classes, shortterm and long-term fellowships). More than ten years ago, the studies noted that the increase in the quality of higher education, particularly the importance of international cooperation in terms of improving the quality of higher education will play a major role in the 21 st century. Increasing the quality of higher education means the mobility of students and teachers, the transnational nature of the development of education; the development of new types of training programs.

It should be noted that the first step in the internationalization of the educational processes is the improvement of our educational programs and plans, and the development of new programs according to the priority "development of education and science" of our country which will create the impulse that stimulates the motivation of the teaching staff in the field of medical education. The most important thing is healthy competition between them, as well as an opportunity to assess the weak areas of their work, to develop concrete proposals to further improve the level and quality of training of qualified specialists.

Since the beginning of 2016 in Uzbekistan there was curriculum reform initiated: all medical schools have revised their programs, reviewed the curricula of the leading medical universities in Europe, America and Asia and on the basis of the research there was modern single program that meets the requirements of today to the training of physicians composed. At this time, the program is implemented in the educational process of first courses in Tashkent Medical Academy (TMA), and receives a lot of positive feedback from teachers and students.

To solve the set goal and verify the initial hypothesis a set of scientific research methods was used in the work, including analysis of scientificmethodical medical and pedagogical literature, related to the problem of this study, the regulatory and legislative documents of the Republic of Uzbekistan on higher education; the search, ascertaining, forming and control conditions of medical and pedagogical science, taking into account our many years of scientific and pedagogical activity in the TMA; methods of quantitative and qualitative 
processing of material; analysis and synthesis of reports with elements of experimental work; polls, conversations, testing.

Special attention is given to the extension of grants opportunities for the development of medical science and educational processes in medicine. The project Internationalization and Modernization of Education and the Processes in Higher Education of Uzbekistan (IMEP) - a joint project of TMA and Rezekne Technological Academy (Latvia), London Metropolitan University (UK) and Peloponness University (Greece) is an example of such cooperation which became a reality thanks to the Erasmus+program. The aim of the project is the internationalization and modernization of processes in higher education, the continuous increase of pedagogical qualification, improving the quality of teaching, bringing students and employersto the learning process. The project involves not only Rezeknes Augstskola, London Metropoilitan University, University of the Peloponesse, but also British Council, Ministry of Higher and Secondary Special Education of the Republic of Uzbekistan, chief scientific and methodological center, Tashkent Medical Academy, University of World Economy and Diplomacy, Uzbek State University of World Languages, Bukhara State University, Namangan State University, Samarkand State Institute of foreign languages and Tashkent State Pedagogical University.

The project is presented with 7 work packages, the aim of which is to analyze the existing needs by questioning of hundreds of teachers and students, tens of employers and focus group -heads of the universities - then on the basis of these results, a program of continuous professional development of teachers, guidance on sustainable and continuous improvement of teaching standards, guidelines to attract students and employers in the learning process will be developed, all steps are carried out under the constant supervision of the quality and completion of the project and by the end all will disseminate the results of the project and put them into practice TMA and other higher educational institutions of the republic.

Today, a lot of work was already accomplished: project website (https://imep.bimm.uz), which houses all of the available information on the project was created, regular working meetings of partners, such as full-time in Tashkent, Namangan, London, and teleconferencing are taking place on regular basis, there are designed questionnaires for institutions' staff, students and employers in three languages, conducted surveys of teachers, students and employers, and the work on preparing the next meeting of the partners in Bukhara and Rezekne is in full swing. There are plans to launch pilot projects to engage into the learning process students and employers, as well as accomplishing the mobility of students and teachers in the project.

As one of the most important international activities of the university is the academic mobility of students, masters, candidates and faculty members, TMA pays special attention to this issue. Gradually universities stepped up existing 
contacts and develop cooperation, making it possible to visit foreign universities (London Metropolitan, Birmingham City universities). So, at the moment about 50 master students have been trained in foreign universities for a period from 1 to 6 months, the applicants were able to get acquainted with the modern methods of scientific research. The teaching staff is involved in the programs of exchange of experience with foreign colleagues, in particular the teaching of the specialty of general practitioners (GPs). The direction of mobility is closely linked to programs for international students and TMA is actively engaged in attracting of foreign students. So, today most foreign students at the Academy are from CIS countries. However, this area still needs to be developed and we also plan to attract English-speaking foreign students, that is why it is necessary to develop a program to work with foreign students. TMA has a great potential for this, as it was one of the flagships of the introduction of English in teaching process among universities of Uzbekistan. TMA has strict requirements for its staff on knowledge of foreign language and teaching partially or completely in it. More and more students of TMA are ready to take training in English that can not but rejoice in the light of the opening of this possibility to exit the prospects of our education on a global level.

\section{The results of the study and their discussion}

Analysis of scientific and methodological literature allowed us to highlight the problems of introducing information and communication technologies in medical education. At the same time, great attention is paid to the psychological and pedagogical problems of using info communication technologies: education in the information and communication environment, interaction of the students with computer, transfer of teaching functions to the computer, pedagogical orientation in the development of electronic means of support and development of the educational process, computer didactics, study of the feedback mechanism.

The components of the information culture of future doctors are determined, the basis of which are the disciplines of the information cycle: medical informatics ( 2 semester), the fundamentals of algorithmization and programming of problems of differential diagnostics of diseases (12 semester).

The main possibilities of info communication technologies in teaching special disciplines are identified:

- obtaining and analysis of various information;

- $\quad$ systematization and logical ordering of the educational material;

- $\quad$ means for developing of thinking through solving problems, modeling various situations;

- $\quad$ preparation of study tasks, methodological and didactic materials. 
Specificity of information training of future doctors lies in the fact that in addition to the fundamental training of future doctors in the field of informatics, they must possess theoretical knowledge and practical skills of effective application of computer training technologies in the educational process of the medical academy; be able to use info communication technologies in solving professional problems.

The possibilities of continuous informational preparation of students in the structure of higher medical education are also considered. Practical realization of the methodical system of teaching students of computer science in TMA is revealed. The main directions of using ICT in teaching and managing medical education are outlined. Priority at the moment are the following areas of informatics: telecommunications, multimedia technologies, object-oriented and visual programming technologies, distributed computing and databases.

Implementation of the recommended measures allows us to specify the goals and objectives of the training in the areas of mathematics and computer science and reasonably determine the depth of their study, and also purposefully select the software of computers in accordance with the profile of a specialist.

The State educational standards of professional higher medical education do not provide for the study of such, in our opinion, important topics as „Philosophical Foundations of Informatics”, „Man in the Information Society”, „Information and Knowledge”, etc.

It is necessary to develop a set of appropriate curricula and include these programs in the curriculum of the university when studying various social disciplines.

\section{Conclusions}

The analysis of the state of the development of information technologies in education, the disclosure of the specifics of the use of ICT allow us to develop organizational and semantic conditions for the formation of elements of the methodical system for using modern information technologies in the professional training of students of medical universities.

Theoretical analysis of professional training of students based on the use of ICT serves as a basis for improving the quality of information training for students of medical schools, their readiness for the continuous use of modern ICT in professional activities.

The considered practical realization of ICT opportunities in teaching students of medical universities contributes to the enhancement of the humanistic and professional orientation of the introduction of modern information technologies in education. 
The results of the studies make it possible to draw a conclusion on the effectiveness of the considered system of using ICT for improving the quality of training of students in medical schools.

Thus, today there are all conditions for the successful implementation in the world educational process and the internationalization of medical education is already actively developing. In general, evaluating the current state of processes of internationalization of higher education in the field of medicine, it should be noted that significant positive results, which the universities have reached in the last decade. It should be emphasized that the integration processes in the world educational space, including the medical field, initiate the development of existing and stimulate the emergence of new forms of international inter-university cooperation in the field of undergraduate, graduate, clinical residency and doctoral programs, which necessitates universities constantly improve the internationalization strategy.

\section{References}

Computers and Medical Informatics in the Curriculum. Contemporary Issues in Medical Education. Association of American Medical Colleges, Division of Medical Education. January 1998, Vol. 1 No. 4.

Lyon, H.C. (2001). Lessons from 15 years of Case-Based Multimedia Education. Slice of Life 2001and Computers Education Symposium Munich, Germany.

Kridl M., Livingston A., Wirt J., Choy S., Gerald D., Provasnik S., Roney P., Watanabe S., Glander R., \& Tobin B. (2001). The Condition of Education 2001. U.S. Department of Education Office of Educational Research and Improvement NCES 2001-072, p.81.

Боймурадов, Ш.А. (20016). Роль вузовской науки в инновационном развитии системы здравоохранения. Материаль IV традиционной научно-практической конференции "Конституция Республики Узбекистан: Наука, образование и воспитание молодёжи".Ташкент, С.42-51.

Боймурадов, Ш.А., Тилляшайхов М.Н., \& Хамраев А.А. (2014). Совершенствование медицинского образования в контексте современной дидактики. Сборник научнометодических статей "Гармонично развитое поколение-условия стабильного развития Республики Узбекистан”, №9.- С.229-241.

Бахарева, Т.А. (2000). Система автоматизированного контроля знаний. Материаль VIII Международной конференции «Открытое образование в России ХХІ века». М.: МЭСИ, с. 25-29.

Васильков, В.Г., \& Сафронов А.И. (2000). Телекоммуникационные технологии и развитие службы медицины критических состояний. Информационные технологии. №6, С. 18-20.

Гулякин, Д.В. (2004). Методическая система обучения социальной информатике в школе. Дисс. к-та пед.наук. Ставрополь.

Долинер, Л.И. (2003). Проблемы внедрения информационных и коммуникационных технологий в обучение. ХIII Конференция «Информационные технологии в образовании», Москва. 16-20 ноября 2003 г. 
Shukhrat Boymuradov, Umida Hodjaeva. Innovative Aspects of Improving the Educational Process in Higher Education

Кочетков, А.Г., Безденежных, А.В., Мельников, А.А., \& Курникова, А.А. (2002). Привлечение средств мультимедиа в учебный процесс кафедры нормальной анатомии, Государственная медицинская академия, Нижний Новгород.

Мирзоева (Магомедова), А.М. (2004). Формирование информационной культурь юристов в процессе профессиональной подготовки. Дисс. к-та пед.наук. Ставрополь.

Романов, А.Н., \& Торопцов В.С. (2002). Комплексная кейс-технология и ее значение для развития системы заочного экономического образования. Образовательныле технологии для новой экономики: Сборник материалов Международной конференциии. М.: Изд. МЭСИ, 376 с.

Шапошникова, Т.Л. (2000). Обучение физике с использованием современных компьютерных технологий: перспективы, достижения и проблемы, Краснодар. 